\title{
Identifying Candidate Genes for Type 2 Diabetes Mellitus and Obesity through Gene Expression Profiling in Multiple Tissues or Cells
}

\author{
Junhui Chen,, ${ }^{1}$ Yuhuan Meng, ${ }^{1,2}$ Jinghui Zhou, ${ }^{1}$ Min Zhuo, ${ }^{1}$ Fei Ling, ${ }^{1}$ Yu Zhang, \\ Hongli Du, ${ }^{1}$ and Xiaoning Wang ${ }^{1,2}$ \\ ${ }^{1}$ School of Bioscience and Bioengineering, Guangdong Provincial Key Laboratory of Fermentation and Enzyme Engineering, \\ South China University of Technology, Guangzhou 510006, China \\ ${ }^{2}$ Chinese PLA General Hospital, Beijing 100853, China \\ ${ }^{3}$ Guangdong Laboratory Animals Monitoring Institute, Guangzhou 510555, China
}

Correspondence should be addressed to Hongli Du; hldu@scut.edu.cn

Received 16 July 2013; Revised 30 September 2013; Accepted 25 October 2013

Academic Editor: Mark A. Yorek

Copyright (C) 2013 Junhui Chen et al. This is an open access article distributed under the Creative Commons Attribution License, which permits unrestricted use, distribution, and reproduction in any medium, provided the original work is properly cited.

\begin{abstract}
Type 2 Diabetes Mellitus (T2DM) and obesity have become increasingly prevalent in recent years. Recent studies have focused on identifying causal variations or candidate genes for obesity and T2DM via analysis of expression quantitative trait loci (eQTL) within a single tissue. T2DM and obesity are affected by comprehensive sets of genes in multiple tissues. In the current study, gene expression levels in multiple human tissues from GEO datasets were analyzed, and 21 candidate genes displaying high percentages of differential expression were filtered out. Specifically, DENND1B, LYN, MRPL30, POC1B, PRKCB, RP4-655J12.3, HIBADH, and TMBIM4 were identified from the T2DM-control study, and BCAT1, BMP2K, CSRNP2, MYNN, NCKAP5L, SAP30BP, SLC35B4, $S P 1, B A P 1, G R B 14, H S P 90 A B 1, I T G A 5$, and TOMM5 were identified from the obesity-control study. The majority of these genes are known to be involved in T2DM and obesity. Therefore, analysis of gene expression in various tissues using GEO datasets may be an effective and feasible method to determine novel or causal genes associated with T2DM and obesity.
\end{abstract}

\section{Introduction}

T2DM, a complex endocrine and metabolic disorder, has become more prevalent in recent years, with significant adverse effects on human health. T2DM is characterized by insulin resistance (IR) and deficient $\beta$-cell function [1]. Interactions between multiple genetic and environmental factors are proposed to contribute to pathogenesis of the disease $[1,2]$. Association of obesity with T2DM has been reported, both within and among different populations [3]. Earlier research has shown that obesity and its duration are major risk factors for T2DM, and IR pathological state generally exists in obesity $[4,5]$.

In recent years, numerous susceptibility loci have been identified through genome-wide association studies (GWAS) and meta-analyses on T2DM and obesity, and nearby candidate genes are proposed to be directly involved in the diseases $[6,7]$. However, the underlying mechanisms by which these susceptibility loci affect and cause T2DM or obesity are currently unclear. Known SNPs associated with disease typically account for only a small fraction of overall disease $[8,9]$. Gene expression patterns play a key role in determining pathogenesis and candidate genes of T2DM and obesity. A large-scale computable model has been created to analyze the molecular actions and effects of insulin on muscle gene expression [10]. Based on GWAS results, investigators integrated expression quantitative trait loci (eQTL) with coexpression networks to establish novel genes and networks relevant to the disease. Sixty-two candidate genes were identified through integrating 32 SNPs associated with T2DM and nearby gene expression from blood samples of 1008 morbidly obese patients. Many of the highly ranked genes are 


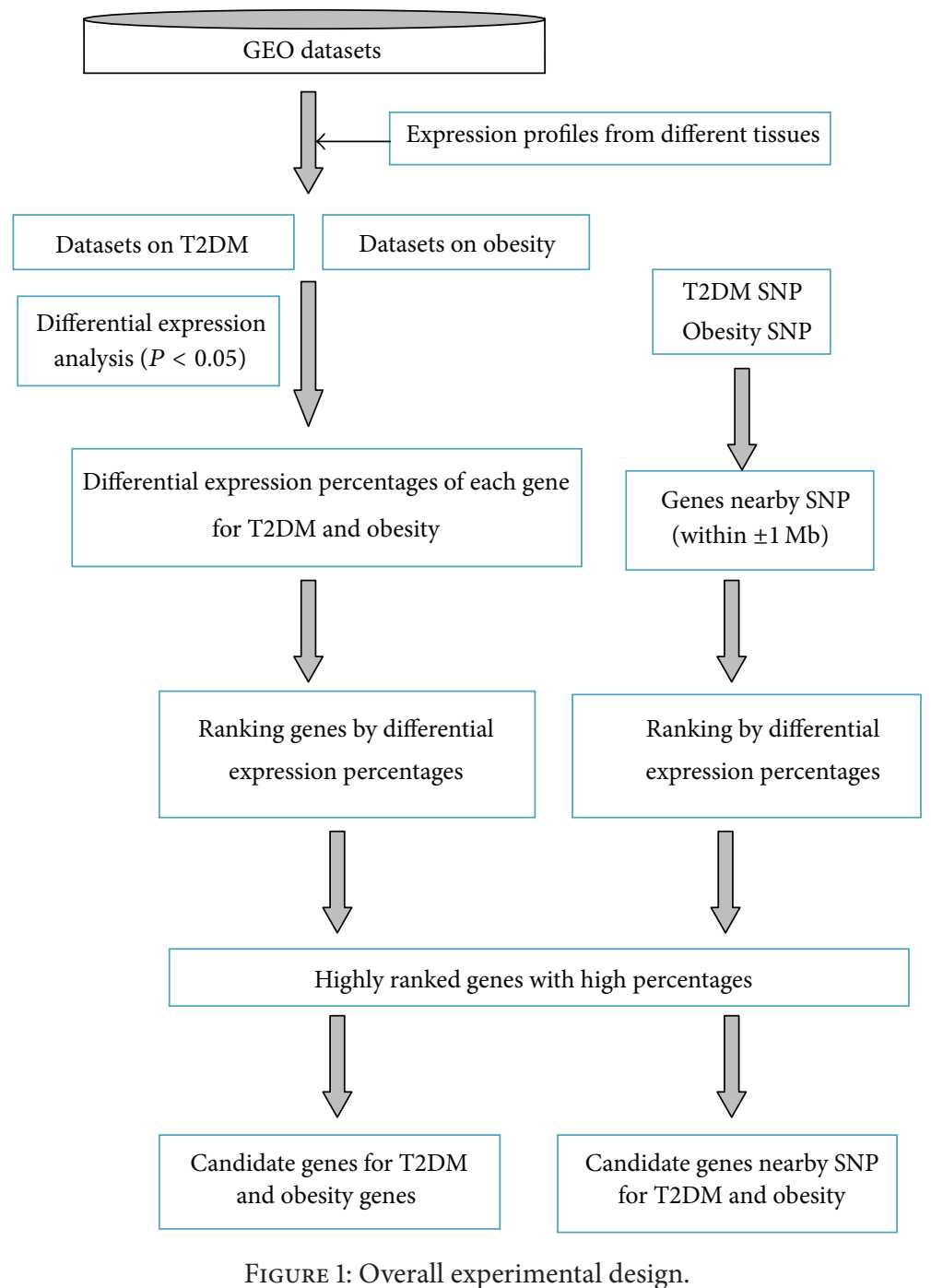

known to be involved in the regulation and metabolism of insulin, glucose, and lipids [11].

Different gene expression patterns exist in various tissues of organisms, and complex metabolic diseases, such as T2DM and obesity, are affected by comprehensive gene expression in multiple tissues. Analysis of gene expression in six tissues of mice from obesity-induced diabetes-resistant and diabetessusceptible strains before and after the onset of diabetes led to the identification of 105 coexpression gene modules [12]. In the present study, gene expression profiles of human skeletal muscle, adipose tissue, islet, liver, blood and arterial tissue (or skeletal muscle, omental adipose tissue, cumulus cells, liver, blood, and subcutaneous abdominal adipose tissue) from GEO datasets were analyzed to identify the candidate genes for T2DM and obesity. Furthermore, candidate genes $1 \mathrm{Mb}$ upstream and downstream $( \pm 1 \mathrm{Mb})$ of susceptibility SNPs for human T2DM and obesity were screened. Our analysis of gene expression in various tissues using GEO datasets provides a valuable method to determine novel candidate genes for T2DM and obesity.

\section{Materials and Methods}

The overall experimental design is shown in Figure 1.

2.1. GEO Dataset Selection and Statistical Analysis. Human GEO datasets for T2DM or obesity were downloaded from the Gene Expression Omnibus (GEO) database of NCBI (http://www.ncbi.nlm.nih.gov/gds/). In total, 23 datasets (14 for T2DM and 9 for obesity) were selected and downloaded. Some datasets were separated into several groups according to sample phenotype. Overall, 21 groups for T2DM and 14 for obesity were obtained. Samples of disease and control were included in the case and control subgroups, respectively (details of samples for each group are provided in Table S1 in Supplementary Material available online at http://dx.doi.org/10.1155/2013/970435). Three or more samples were included in each case or control subgroup for every microarray experiment. CEL files of samples were submitted to RMAExpress, Version 1.0.4, to yield normalized $\log _{2}$ expression values for each probe in individual groups 
with default parameters [13]. Analysis of variance (ANOVA) for normalized $\log _{2}$ expression values of two independent samples in each group was performed with the $F$ test. The $t$-test for equal or unequal variances was used, depending on the $P$-value of the $F$ tests.

Gene annotation files were downloaded from Ensembl (http://asia.ensembl.org/biomart/martview/45e0798c53bbd97ed0cf3d61142da3df) depending on the platform (GPL) of each group. Probes were matched with unique genes through gene annotation files. Probes corresponding to more than one gene were excluded. Probes or genes with significant differential expression were defined as $P$-value $\leq 0.05$. We calculated the differential expression $(P \leq 0.05)$ percentage of each gene in all $21 \mathrm{~T} 2 \mathrm{DM}$ and 14 obesity groups. For a gene with several probes, $P$ values $\leq 0.05$ were selected to represent significance.

2.2. Statistical Analysis of Differential Expression Percentages of Genes. Genes were ranked based on differential expression in the T2DM and obesity groups. Genes with the highest percentage of differential expression were identified as candidates ( $\geq 50 \%$ for $\mathrm{T} 2 \mathrm{DM}$ and $\geq 60 \%$ for obesity). Ranked genes are presented in Supplementary Materials (Table S2).

2.3. Screening of Genes within $\pm 1 M b$ of Susceptibility SNPs for T2DM and Obesity. In total, 54 and 95 SNPs associated with T2DM and obesity, respectively, were selected $(P \leq$ $5 \times 10^{-8}$, detailed information in Tables S3 and S4). The coordinate of each SNP in the chromosome was searched in the NCBI database (http://www.ncbi.nlm.nih.gov/SNP/). Consensus CDS (CCDS) files for human data were downloaded (ftp://ftp.ncbi.nlm.nih.gov/pub/CCDS/), and genes within $\pm 1 \mathrm{Mb}$ of SNPs were filtered out. Overall, 445 and 917 genes within $2 \mathrm{Mb}$ of SNPs were associated with T2DM and obesity, respectively. The genes were reordered based on differential expression percentages with the above method, and those with the highest percentages were selected as candidates for T2DM $(>40 \%)$ and obesity $(>50 \%)$. Detailed information on all ranked genes in close proximity to SNPs is provided in Supplementary Materials (Table S5).

2.4. GO (Gene Ontology) and Pathway Analysis of Candidate Genes. Enrichment analysis of GO and pathways of all candidate genes was performed using Capital Bio Molecule Annotation System 3 (http://bioinfo.capitalbio.com/mas3/).

\section{Results}

3.1. Candidate Genes for T2DM and Obesity. In total, expression patterns of 23,810 genes were analyzed in the T2DMcontrol study. All genes were ranked based on the differential expression percentage. The average percentage of all genes was $\sim 11 \%$. Six highly ranked genes (DENND1B, LYN, MRPL30, POC1B, PRKCB, and RP4-655J12.3) were identified as candidates for T2DM (Table 1).

Since less groups were available for the obesity-control study, genes with fewer than $10 P$ values were excluded in order to obtain better statistical results. Expression of 14,367 genes was analyzed using the above method. The average percentage of all genes was $\sim 17.5 \%$. Eight genes (BCAT1, BMP2 K, CSRNP2, MYNN, NCKAP5L, SAP3OBP, SLC35B4, and $S P 1$ ) were isolated as candidates for obesity (Table 2).

3.2. Candidate Genes within $\pm 1 M b$ of SNPs Conferring Susceptibility to T2DM and Obesity. In total, 445 genes in close proximity to T2DM SNPs were reordered based on their differential expression percentages. In particular, two highly ranked genes, HIBADH and TMBIM4, within $\pm 1 \mathrm{Mb}$ of rs864745, rs849134, and rs1531343 SNPs were filtered out (Table 1).

Using the same method, seven highly ranked genes (BAP1, GRB14, HSP90AB1, ITGA5, NCKAP5L, SP1, and TOMM5) within $\pm 1 \mathrm{Mb}$ of obesity SNPs were identified (Table 2).

Gene symbols and the corresponding full names of all candidate genes are supplied in Tables 1 and 2.

3.3. GO and Pathway Analysis of Candidate Genes. Results of GO and pathway analyses revealed that $P R K C B$ is mainly associated with T2DM, and PRKCB and GRB14 are involved in insulin signaling within the gene pathway network (Figure 2). Further analysis of the correlation pathways of genes disclosed that PRKCB, SP1, GRB14, LYN, and ITGA5 are correlated with each other (Figure 3 ).

\section{Discussion}

Complex metabolic diseases are often caused by alterations in gene expression or metabolic pathways in various tissues. Here, we analyzed differences in gene expression levels in various human tissues from GEO datasets in T2DM- or obesity-control experiments with the $t$-test. The $P$ values were adjusted using the Bonferroni or FDR method [20] to allow for multiple testing. We introduced strict criteria with FDR $\leq 0.05$. However, with these criteria, no genes were filtered out in most groups (16 of 21 groups, Table S6), while the percentage of genes with $t$-test $P$ values $\leq 0.05$ was lower than $10 \%$ in most groups (15 of 21 groups, Table S6). Therefore, the $t$-test statistic was ultimately applied for the present study. In total, we filtered out 21 candidate genes ( 8 for T2DM and 13 for obesity). The list of up- and downregulated candidate genes is provided in Supplementary Material (Table S7). Similarly, an eGWAS was performed across 130 independent experiments in human, rat, and mouse to identify additional genes implicated in the molecular pathogenesis of T2DM [21]. Interestingly, the same genes were not identified among the different studies. These discrepancies may be attributed to the use of various species, statistical methods, and tissues by different groups.

Analysis of the correlation pathways of the identified genes revealed that PRKCB, SP1, GRB14, LYN, and ITGA5 are correlated with each other (Figures 2 and 3 ). The proteins interact directly within cells or indirectly among different tissues in the etiological process of T2DM or obesity. PRKCB mediates $\mathrm{Ca}^{2+}$ and DAG-evoked insulin secretion processes 
TABLE 1: Highly ranked genes in T2DM-control study.

(a) Highly ranked genes with high percentages in T2DM-control study

\begin{tabular}{|c|c|c|c|c|}
\hline Gene symbol & Official full name & Location & Percentage & References \\
\hline$L Y N$ & $\begin{array}{l}\text { v-yes-1 Yamaguchi } \\
\text { sarcoma viral related } \\
\text { oncogene homolog }\end{array}$ & $\begin{array}{c}\text { Chr8 } \\
56,792,386-56,925,006(+): 8 q 13\end{array}$ & $61.1 \%$ & $\begin{array}{l}\text { Müller et al., } \\
2000[14]\end{array}$ \\
\hline DENND1B & $\begin{array}{c}\text { DENN } \\
\text { domain-containing } \\
\text { protein } 1 \mathrm{~B} \\
\end{array}$ & $\begin{array}{c}\text { Chr1 } \\
197,473,878-197,744,623(-): 1 q 31.3\end{array}$ & $50 \%$ & \\
\hline MRPL30 & $\begin{array}{c}\text { Mitochondrial } \\
\text { ribosomal protein L30 }\end{array}$ & $\begin{array}{c}\text { Chr2 } \\
99,797,542-99,816,020(+): 2 q 11.2 \\
\end{array}$ & $50 \%$ & \\
\hline POC1B & $\begin{array}{l}\text { POC1 centriolar } \\
\text { protein homolog B } \\
\text { (Chlamydomonas) }\end{array}$ & $\begin{array}{c}\text { Chr12 } \\
89,813,495-89,920,039(-): 12 q 21.33\end{array}$ & $50 \%$ & \\
\hline$P R K C B$ & $\begin{array}{c}\text { Protein kinase C } \\
\text { betatype PKC-beta } \\
\text { (PKC-B) }\end{array}$ & $\begin{array}{c}\text { Chr16 } \\
23,847,300-24,231,932(+): 16 p 11.2 \\
\end{array}$ & $50 \%$ & $\begin{array}{l}\text { Zhang et al., } \\
2004 \text { [22] }\end{array}$ \\
\hline$R P 4-655 J 12.3$ & & $\begin{array}{c}\text { Chr1 } \\
116,916,755-116,917,283(-): \text { N/A }\end{array}$ & $50 \%$ & \\
\hline
\end{tabular}

(b) Highly ranked genes nearby SNPs conferring susceptibility to T2DM

\begin{tabular}{|c|c|c|c|c|c|}
\hline Gene symbol & Official full name & Location & Percentage & References & $\begin{array}{c}\text { SNPs } \\
\text { (Chr pos; frequencies) }\end{array}$ \\
\hline$H I B A D H$ & $\begin{array}{l}\text { 3-Hydroxyisobutyrate } \\
\text { dehydrogenase }\end{array}$ & $\begin{array}{c}\text { Chr7 } \\
\text { 27,565,059-27,702,620 (-): 7p15.2 }\end{array}$ & $42.9 \%$ & $\begin{array}{l}\text { Deng } \\
\text { et al., 2010 } \\
{[15]}\end{array}$ & $\begin{array}{c}\operatorname{rs} 864745 \\
(28,180,556 ; T=0.65, C=0.35) ; \\
\operatorname{rs} 849134 \\
(28,196,222 ; A=0.65, G=0.35)\end{array}$ \\
\hline TMBIM4 & $\begin{array}{l}\text { Transmembrane BAX } \\
\text { inhibitor motif } \\
\text { containing } 4\end{array}$ & $\begin{array}{c}\text { Chr12 } \\
66,530,717-66,563,807 \text { (-): 12q14.1-q15 }\end{array}$ & $42.9 \%$ & & $\begin{array}{c}\mathrm{rs} 1531343 \\
(66,174,894 ; G=0.81, C=0.19)\end{array}$ \\
\hline
\end{tabular}

Note: Chr pos: chromosome position; frequencies: the allele frequencies in 1000 genomes (http://www.ncbi.nlm.nih.gov/variation/tools/1000genomes/).

in Langerhans' $\beta$ cells [22], functions downstream of insulinreceptor substrate 1 (IRS1) in muscle cells, and participates in the regulation of glucose transport in adipocytes by negatively modulating insulin-stimulated translocation of the glucose transporter, SLC2A4/GLUT4 [23, 24]. Under high glucose conditions in pancreatic beta cells, $P R K C B$ may be involved in the inhibition of insulin gene transcription [25]. In the present study, we observed PRKCB upregulation in skeletal muscle, islets, adipose tissue, and blood and downregulation in liver of T2DM individuals (Table S7). These findings suggest that $P R K C B$ may be involved in IR and deficient $\beta$-cell function in vivo. GRB14 binds directly to IR and regulates insulin-induced IR tyrosine phosphorylation [19]. GRB14-deficient mice display enhanced insulin signaling via IRS1 and AKT activation in liver and skeletal muscle, despite lower circulating insulin levels [18]. An earlier study showed increased GRB14 expression in adipose tissues of both ob/ob mice and Goto-Kakizaki (GK) rats, but no changes in liver [26]. In our experiments, GRB14 expression was similarly increased in subcutaneous adipose tissue of obese humans, while a decrease was observed in liver (Table S7). In addition, GRB14 is located within $\pm 1 \mathrm{Mb}$ of obese SNP rs10195252, and the rs10195252 T-allele is associated with increased GRB14 subcutaneous adipose tissue mRNA expression [27]. However, $L Y N$ is implicated in the insulin signaling pathway via phosphorylation of IRS1 and PI3 K in liver and adipose tissues
[14]. The insulin secretagogue, glimepiride, activates $L Y N$ in adipocytes [28]. This indirect $L Y N$ activation may modulate glycemic control activity of glimepiride in the extrapancreatic environment $[28,29]$. In the present study, $L Y N$ expression was increased in adipose tissue, skeletal muscle, and blood of T2DM individuals, while a decrease was observed in islets and liver (Table S7). Moreover, $L Y N$ is a highly ranked gene with the highest differential expression percentage in the T2DM-control study (61.1\%) and may therefore be a valuable candidate gene for future T2DM research. ITGA5 additionally promotes PI3 K and AKT phosphorylation [30]. ITGA5 expression was shown to be upregulated in adipose tissue of New Zealand obese (NZO) mice (high fat diet versus standard diet) [31]. We observed increased expression of ITGA5 in human subcutaneous adipose tissue (Table S7). Moreover, ITGA5 is located within $\pm 1 \mathrm{Mb}$ of the obesity SNP, rs1443512. SP1 is a zinc finger transcription factor that binds to GC-rich motifs and may be involved in insulinmediated glucose uptake through positively regulating Glut 4 expression in adipose tissue, skeletal muscle, and heart [32, 33]. SP1 was downregulated in adipose tissue, while increased expression was observed in blood. Pathway analysis revealed the involvement of $S P 1$ in oxidative stress and adipogenesis (Figure 2). SP1 not only is located within $\pm 1 \mathrm{Mb}$ of obesity SNP rs1443512 (similar to ITGA5), but also has the highest differential expression percentage (63.6\%). Therefore, further 
TABLE 2: Highly ranked genes in the obesity-control study.

(a) Highly ranked genes with high percentages in obesity-control study

\begin{tabular}{|c|c|c|c|c|}
\hline Gene symbol & Official full name & Location & Percentage & References \\
\hline BCAT1 & $\begin{array}{l}\text { Branched chain } \\
\text { amino-acid } \\
\text { transaminasel } \\
\end{array}$ & $\begin{array}{c}\text { Chr12 } \\
24,962,958-25,102,393(-): 12 p 12.1\end{array}$ & $63.6 \%$ & \\
\hline$B M P 2 K$ & $\begin{array}{l}\text { BMP2 inducible } \\
\text { kinase }\end{array}$ & $\begin{array}{c}\text { Chr4 } \\
79,697,532-79,833,341(+): 4 q 21.21\end{array}$ & $63.6 \%$ & \\
\hline CSRNP2 & $\begin{array}{l}\text { Cysteine-serine-rich } \\
\text { nuclear protein } 2\end{array}$ & $\begin{array}{c}\text { Chr12 } \\
51,454,988-51,477,454(-): 12 q 13.11-q 13.12 \\
\end{array}$ & $63.6 \%$ & \\
\hline$M Y N N$ & Myoneurin & $\begin{array}{c}\text { Chr3 } \\
169,490,853-169,507,504(+): 3 q 26.2 \\
\end{array}$ & $63.6 \%$ & $\begin{array}{c}\text { Stewart et al., } 2010 \\
{[38]}\end{array}$ \\
\hline NCKAP5L & $\begin{array}{l}\text { NCK-associated } \\
\text { protein 5-like }\end{array}$ & $\begin{array}{c}\text { Chr12 } \\
50,184,929-50,222,208(-): 12 q 13.12\end{array}$ & $63.6 \%$ & \\
\hline SAP30BP & $\begin{array}{l}\text { SAP30 binding } \\
\text { protein }\end{array}$ & $\begin{array}{c}\text { Chr17 } \\
73,663,399-73,704,139(+): 17 q 25.1 \\
\end{array}$ & $63.6 \%$ & $\begin{array}{c}\text { Naukkarinen et al., } \\
2010[39]\end{array}$ \\
\hline SLC35B4 & $\begin{array}{l}\text { Solute carrier family } \\
35 \text {, member B4 }\end{array}$ & $\begin{array}{c}\text { Chr7 } \\
133,974,089-134,001,827(-): 7 q 33\end{array}$ & $63.6 \%$ & $\begin{array}{c}\text { Fox et al., } 2007 \\
\text { [16]; Yazbek et al., } \\
2011[17] \\
\end{array}$ \\
\hline$S P 1$ & $\begin{array}{l}\text { Sp1 transcription } \\
\text { factor }\end{array}$ & $\begin{array}{c}\text { Chr12 } \\
53,773,979-53,810,230(+): 12 q 13.1\end{array}$ & $63.6 \%$ & \\
\hline
\end{tabular}

(b) Highly ranked genes nearby SNPs conferring susceptibility to obesity

\begin{tabular}{|c|c|c|c|c|c|}
\hline Gene symbol & $\begin{array}{l}\text { Official full } \\
\text { name }\end{array}$ & Location & Percentage & References & $\begin{array}{c}\text { SNPs } \\
\text { (Chr pos; frequencies) }\end{array}$ \\
\hline NCKAP5L & $\begin{array}{l}\text { NCK-associated } \\
\text { protein 5-like }\end{array}$ & $\begin{array}{c}\text { Chr12 } \\
50,184,929-50,222,208(-): 12 q 13.12\end{array}$ & $63.6 \%$ & & $\begin{array}{c}\text { rs7132908 } \\
(50,263,148 ; G=0.73 ; A=0.27)\end{array}$ \\
\hline$S P 1$ & $\begin{array}{l}\text { Sp1 } \\
\text { transcription } \\
\text { factor }\end{array}$ & $\begin{array}{c}\text { Chr12 } \\
53,773,979-53,810,230(+): 12 q 13.12\end{array}$ & $63.6 \%$ & & $\begin{array}{c}\text { rs1443512 } \\
(54,342,684 ; A=0.31 ; C=0.69)\end{array}$ \\
\hline ITGA5 & Integrin, alpha 5 & $\begin{array}{c}\text { Chr12 } \\
54,789,045-54,813,050(-): 12 q 11-q 13\end{array}$ & $58.3 \%$ & & $\begin{array}{c}\mathrm{rs} 1443512 \\
(54,342,684 ; A=0.31 ; C=0.69)\end{array}$ \\
\hline TOMM5 & $\begin{array}{l}\text { Translocase of } \\
\text { outer } \\
\text { mitochondrial } \\
\text { membrane } 5\end{array}$ & $\begin{array}{c}\text { Chr9 } \\
37,588,410-37,592,636(-): 9 p 13.2\end{array}$ & $57.1 \%$ & & $\begin{array}{c}\mathrm{rs} 16933812 \\
(36,969,205 ; G=0.40, T=0.60)\end{array}$ \\
\hline HSP90AB1 & $\begin{array}{c}\text { Heat shock } \\
\text { protein } 90 \mathrm{kDa} \\
\text { alpha } \\
\text { (cytosolic), class } \\
\text { B member } 1\end{array}$ & $\begin{array}{c}\text { Chr6 } \\
44,214,849-44,221,614(+): 6 p 12\end{array}$ & $55.6 \%$ & & $\begin{array}{c}\text { rs6905288 } \\
(43,758,873 ; G=0.38, A=0.62)\end{array}$ \\
\hline$B A P 1$ & $\begin{array}{c}\text { BRCA1 } \\
\text { associated } \\
\text { protein-1 }\end{array}$ & $\begin{array}{c}\text { Chr3 } \\
52,435,024-52,444,009(-): 3 p 21.31-p 21.2\end{array}$ & $50 \%$ & & $\begin{array}{c}\mathrm{rs} 6784615 \\
(52,506,426 ; C=0.04, T=0.96)\end{array}$ \\
\hline GRB14 & $\begin{array}{l}\text { Growth factor } \\
\text { receptor-bound } \\
\text { protein } 14\end{array}$ & $\begin{array}{c}\text { Chr2 } \\
165,349,323-165,478,360(-): 2 q 22-q 24\end{array}$ & $50 \%$ & $\begin{array}{c}\text { Cooney } \\
\text { et al., } 2004 \\
\text { [18]; Holt } \\
\text { et al., 2009. } \\
{[19]}\end{array}$ & $\begin{array}{c}\mathrm{rs} 10195252 \\
(165,513,091 ; T=0.60, C=0.40)\end{array}$ \\
\hline
\end{tabular}

Note: Chr pos: chromosome position; frequencies: the allele frequencies in 1000 genomes (http://www.ncbi.nlm.nih.gov/variation/tools/1000genomes/).

studies are necessary to determine whether rs1443512 is related to ITGA5 or SP1 expression.

Differential expression of HIBADH ((+) 5.1e - 03) was reported in liver mitochondria during development of Goto-Kakizaki (GK) rats [15]. We observed no changes in HIBADH expression in liver, while a decrease was evident in skeletal muscle and blood of humans with T2DM. In addition, $H I B A D H$ is located within $\pm 1 \mathrm{Mb}$ of T2DM SNPs, rs864745, and rs849134. The association of $H I B A D H$ with T2DM requires further evaluation.An earlier study reported higher $B C A T 1$ expression in subcutaneous adipose tissue of females in the insulin-resistant than insulin-sensitive group [34]. Interestingly, higher BCAT1 expression was observed in subcutaneous adipose tissue of obese humans in this 


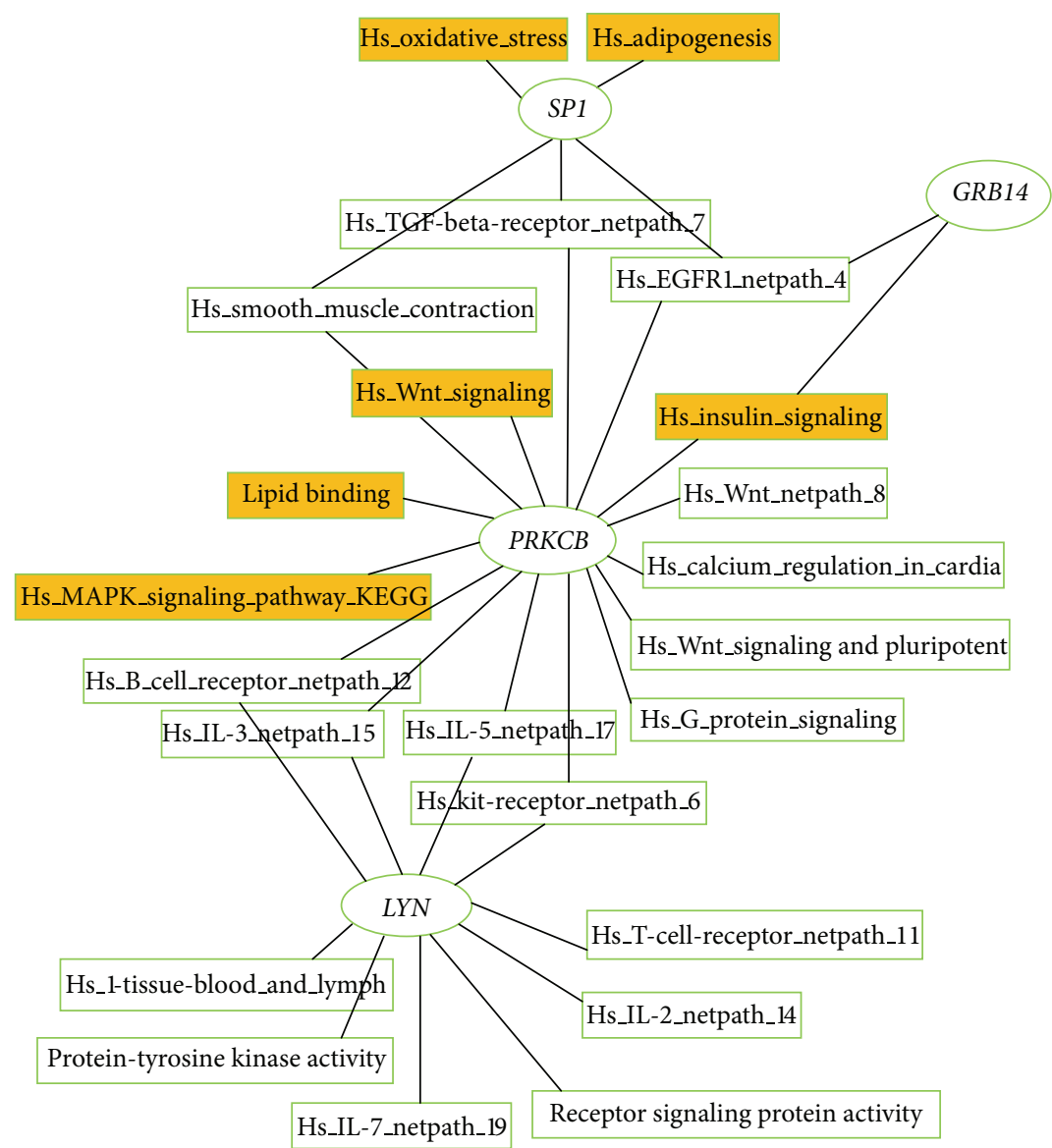

FIGURE 2: Enrichment analysis of GO and pathways for all genes. Yellow represents pathway directly or indirectly related to T2DM or obesity.

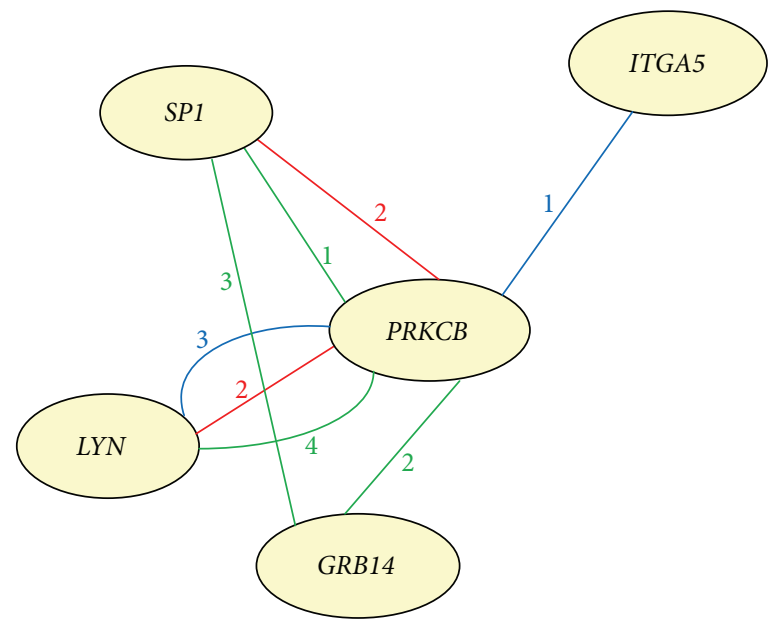

FIGURE 3: Correlation pathways of candidate genes. Red line, BioCarta; green line, GenMAPP; blue line, KEGG; number: counts of correlation pathways of two genes.

study. We additionally recorded an increase in blood and decrease in omental adipose tissue (Table S7). BCAT1 has been identified as the optimal marker for weight regain [35]. Moreover, the rs2242400 polymorphism in BCAT1 appears to be associated with T2DM in more than one population [36]. SLC35B4 has been identified as a potential regulator of obesity and insulin resistance in mouse models. Both in vivo and in vitro studies in mice disclosed that decreased SLC35B4 expression is associated with a decrease in gluconeogenesis [17]. An increase in SLC35B4 expression was observed in subcutaneous adipose tissue of obese humans in our study (Table S7). Interestingly, a SNP in the human SLC35B4 
gene (rs1619682) is associated with waist circumference [16]. HSP90AB1 mRNA is reported to be upregulated in 3T3L1 cells $6 \mathrm{~h}$ after stimulation of adipogenesis [37]. Moreover, HSP90AB1 is located near the obesity SNP, rs6905288. Expression levels of MYNN are negatively correlated to BW (body weight) in adipose tissues of F2 mice (C57BL/6J $\times$ TALLYHO/JngJ) [38]. Consistently, our data showed that $M Y N N$ expression is downregulated in subcutaneous adipose of obese humans (Table S7). Furthermore, SAP30BP may be involved in body mass index (BMI) in adipose tissue (Pearson correlation (-0.51)) [39]. A decrease in SAP30BP expression was detected in subcutaneous adipocytes of obese human subjects in the present study (Table S7).

The rest of the candidates, C2orf15, DENND1B, MRPL30, POC1B, RP4-655J12.3, TMBIM4, BMP2 K, CSRNP2, NCKAP5L, TOMM5, and BAP1, may be novel genes related to T2DM or obesity. TMBIM4 is located within $\pm 1 \mathrm{Mb}$ of the SNP rs1531343 conferring susceptibility to T2DM, while NCKAP5L, TOMM5, and BAP1 are mapped within $\pm 1 \mathrm{Mb}$ of SNPs conferring susceptibility to obesity. TMBIM4 encodes transmembrane BAX inhibitor motif containing 4 , which inhibits apoptosis induced by intrinsic and extrinsic stimuli and modulates both capacitative $\mathrm{Ca}^{2+}$ entry and inositol 1,4,5-trisphosphate (IP3)-mediated $\mathrm{Ca}^{2+}$ release [40]. In our study, TMBIM4 was mainly upregulated in skeletal muscle, while downregulation was observed in liver (Table S7). The NCKAP5L gene encoding Nck-associated protein 5-like displayed upregulation in adipose tissue but was downregulated in blood (Table S7). TOMM5 encodes the mitochondrial import receptor subunit TOM5 homolog. TOMM5 was mainly involved in four GO terms (GO:0008565, protein transporter activity; GO:0015031, protein transport; GO:0005739, mitochondrion; GO:0005742, mitochondrial outer membrane). BAP1 (ubiquitin carboxyl-terminal hydrolase) localizes at the nucleus and contains three domains (a ubiquitin carboxylterminal hydrolase $(\mathrm{UCH})$ with an N-terminal catalytic domain, a unique linker region, and a C-terminal domain). The UCH domain conveys deubiquitinase activity to BAP1 [41]. In flies and humans, the Polycomb repressive deubiquitinase (PR-DUB) complex is formed through interactions of BAP1 and ASXL1 [42]. DENND1B may promote the exchange of GDP with GTP and play a role in clathrin-mediated endocytosis [43]. The product of MRPL30 is a constituent of mitochondrial ribosomes. $P O C 1 B$ is involved in the early steps of centriole duplication and the later steps of centriole length control $[44,45]$. The CSRNP2 protein binds to the consensus sequence, $5^{\prime}$-AGAGTG- $3^{\prime}$, and has a transcriptional activator. However, C2orf15 and $R P 4-655 J 12.3$ have been rarely reported in databases or publications to date. Associations of all new candidate genes identified in the present study with obesity or T2DM require verification in future analyses.

\section{Conclusions}

$L Y N$, a gene reported to be involved in the insulin pathway, was highly ranked with the highest differential expression percentage in the T2DM-control study (61.1\%) and may therefore be a valuable candidate gene for future T2DM research. NCKAP5L with the highest differential expression percentage (63.6\%) was located within $\pm 1 \mathrm{Mb}$ of the obesity susceptibility SNP, rs7132908, and was thus identified as the most likely novel candidate gene for obesity. We conclude that analysis of gene expression in various tissues via GEO datasets is an effective and feasible method to identify novel or causal genes associated with T2DM and obesity.

\section{Conflict of Interests}

The authors declare that they have no conflict of interests.

\section{Acknowledgments}

This study was funded by the National Science and Technology Major Project of Key Drug Innovation and Development (2011ZX09307-303-03), the National Natural Science Foundation of China (31340045), the Science and Technology Planning Project of Guangdong Province, China (2012B060300006), the Fundamental Research Funds for the Central Universities (2012zz0091), and the BGI-SCUT Innovation Fund Project (SW20130802).

\section{References}

[1] M. Stumvoll, B. J. Goldstein, and T. W. Van Haeften, "Type 2 diabetes: principles of pathogenesis and therapy," The Lancet, vol. 365, no. 9467, pp. 1333-1346, 2005.

[2] G. V. Z. Dedoussis, A. C. Kaliora, and D. B. Panagiotakos, "Genes, diet and type 2 diabetes mellitus: a review," Review of Diabetic Studies, vol. 4, no. 1, pp. 13-24, 2007.

[3] K. M. West and J. M. Kalbfleisch, "Influence of nutritional factors on prevalence of diabetes," Diabetes, vol. 20, no. 2, pp. 99-108, 1971.

[4] S. M. Haffner, M. P. Stern, B. D. Mitchell, H. P. Hazuda, and J. K. Patterson, "Incidence of type II diabetes in Mexican Americans predicted by fasting insulin and glucose levels, obesity, and body-fat distribution," Diabetes, vol. 39, no. 3, pp. 283-288, 1990.

[5] S. Lillioja, D. M. Mott, M. Spraul et al., "Insulin resistance and insulin secretory dysfunction as precursors of non- insulindependent diabetes mellitus: prospective studies of Pima Indians," The New England Journal of Medicine, vol. 329, no. 27, pp. 1988-1992, 1993.

[6] T. Fall and E. Ingelsson, "Genome-wide association studies of obesity and metabolic syndrome," Molecular and Cellular Endocrinology, 2012.

[7] B. F. Voight, L. J. Scott, V. Steinthorsdottir et al., "Twelve type 2 diabetes susceptibility loci identified through large-scale association analysis," Nature Genetics, vol. 42, pp. 579-589, 2010.

[8] J. Dupuis, C. Langenberg, I. Prokopenko et al., "New genetic loci implicated in fasting glucose homeostasis and their impact on type 2 diabetes risk," Nature Genetics, vol. 42, pp. 105-116, 2010.

[9] J. P. Pandey, "Genomewide association studies and assessment of risk of disease," The New England Journal of Medicine, vol. 363, no. 21, pp. 2076-2077, 2010.

[10] J. Pollard Jr., A. J. Butte, S. Hoberman, M. Joshi, J. Levy, and J. Pappo, "A computational model to define the molecular 
causes of type 2 diabetes mellitus," Diabetes Technology and Therapeutics, vol. 7, no. 2, pp. 323-336, 2005.

[11] H. P. Kang, X. Yang, R. Chen et al., "Integration of diseasespecific single nucleotide polymorphisms, expression quantitative trait loci and coexpression networks reveal novel candidate genes for type 2 diabetes," Diabetologia, vol. 55, pp. 2205-2213, 2012.

[12] M. P. Keller, Y. Choi, P. Wang et al., "A gene expression network model of type 2 diabetes links cell cycle regulation in islets with diabetes susceptibility," Genome Research, vol. 18, no. 5, pp. 706716, 2008.

[13] B. M. Bolstad, R. A. Irizarry, M. Åstrand, and T. P. Speed, "A comparison of normalization methods for high density oligonucleotide array data based on variance and bias," Bioinformatics, vol. 19, no. 2, pp. 185-193, 2003.

[14] G. Müller, S. Wied, and W. Frick, "Cross talk of pp125(FAK) and pp59(Lyn) non-receptor tyrosine kinases to insulin-mimetic signaling in adipocytes," Molecular and Cellular Biology, vol. 20, no. 13, pp. 4708-4723, 2000.

[15] W.-J. Deng, S. Nie, J. Dai, J.-R. Wu, and R. Zeng, "Proteome, phosphoproteome, and hydroxyproteome of liver mitochondria in diabetic rats at early pathogenic stages," Molecular and Cellular Proteomics, vol. 9, no. 1, pp. 100-116, 2010.

[16] C. S. Fox, N. Heard-Costa, L. A. Cupples, J. Dupuis, R. S. Vasan, and L. D. Atwood, "Genome-wide association to body mass index and waist circumference: the Framingham Heart Study $100 \mathrm{~K}$ project," BMC Medical Genetics, vol. 8, supplement 1, article S18, 2007.

[17] S. N. Yazbek, D. A. Buchner, J. M. Geisinger et al., "Deep congenic analysis identifies many strong, context-dependent QTLs, one of which, Slc35b4, regulates obesity and glucose homeostasis," Genome Research, vol. 21, no. 7, pp. 1065-1073, 2011.

[18] G. J. Cooney, R. J. Lyons, A. J. Crew et al., "Improved glucose homeostasis and enhanced insulin signalling in Grbl4-deficient mice," The EMBO Journal, vol. 23, no. 3, pp. 582-593, 2004.

[19] L. J. Holt, R. J. Lyons, A. S. Ryan et al., "Dual ablation of Grb10 and Grb14 in mice reveals their combined role in regulation of insulin signaling and glucose homeostasis," Molecular Endocrinology, vol. 23, no. 9, pp. 1406-1414, 2009.

[20] Y. Pawitan, S. Michiels, S. Koscielny, A. Gusnanto, and A. Ploner, "False discovery rate, sensitivity and sample size for microarray studies," Bioinformatics, vol. 21, no. 13, pp. 30173024, 2005.

[21] K. Kodama, M. Horikoshi, K. Toda et al., "Expression-based genome-wide association study links the receptor CD44 in adipose tissue with type 2 diabetes," Proceedings of the National Academy of Sciences of the United States of America, vol. 109, pp. 7049-7054, 2012.

[22] H. Zhang, M. Nagasawa, S. Yamada, H. Mogami, Y. Suzuki, and I. Kojima, "Bimodal role of conventional protein kinase $\mathrm{C}$ in insulin secretion from rat pancreatic $\beta$ cells," Journal of Physiology, vol. 561, no. 1, pp. 133-147, 2004.

[23] M. L. Standaert, L. Galloway, P. Karnam, G. Bandyopadhyay, J. Moscat, and R. V. Farese, "Protein kinase $\mathrm{C}-\zeta$ as a downstream effector of phosphatidylinositol 3- kinase during insulin stimulation in rat adipocytes. Potential role in glucose transport," Journal of Biological Chemistry, vol. 272, no. 48, pp. 3007530082, 1997.

[24] D. C. Wright, C. A. Fick, J. B. Olesen, and B. W. Craig, "Evidence for the involvement of a phospholipase $\mathrm{C}$-protein kinase $\mathrm{C}$ signaling pathway in insulin stimulated glucose transport in skeletal muscle," Life Sciences, vol. 73, no. 1, pp. 61-71, 2003.

[25] C. M. Taniguchi, B. Emanuelli, and C. R. Kahn, "Critical nodes in signalling pathways: insights into insulin action," Nature Reviews Molecular Cell Biology, vol. 7, no. 2, pp. 85-96, 2006.

[26] B. Cariou, N. Capitaine, V. Le Marcis et al., "Increased adipose tissue expression of Grb14 in several models of insulin resistance," The FASEB Journal, vol. 18, no. 9, pp. 965-967, 2004.

[27] D. Schleinitz, N. Kloting, C. M. Lindgren et al., "Fat depotspecific mRNA expression of novel loci associated with waisthip ratio," International Journal of Obesity, 2013.

[28] G. Müller, "The molecular mechanism of the insulinmimetic/sensitizing activity of the antidiabetic sulfonylurea drug Amaryl," Molecular Medicine, vol. 6, no. 11, pp. 907-933, 2000.

[29] G. Müller, A. Schulz, S. Wied, and W. Frick, "Regulation of lipid raft proteins by glimepiride- and insulin-induced glycosylphosphatidylinositol-specific phospholipase C in rat adipocytes," Biochemical Pharmacology, vol. 69, no. 5, pp. 761$780,2005$.

[30] R. Urtasun, A. Lopategi, J. George et al., "Osteopontin, an oxidant stress sensitive cytokine, up-regulates collagen-I via integrin $\alpha \mathrm{V} \beta 3$ engagement and PI3K/pAkt/NFאB signaling," Hepatology, vol. 55, no. 2, pp. 594-608, 2012.

[31] A. Balwierz, A. Polus, U. Razny et al., "Angiogenesis in the New Zealand obese mouse model fed with high fat diet," Lipids in Health and Disease, vol. 8, article 13, 2009.

[32] B. B. Kahn, "Glucose transport: pivotal step in insulin action," Diabetes, vol. 45, no. 11, pp. 1644-1654, 1996.

[33] J. Rüegg, W. Cai, M. Karimi et al., "Epigenetic regulation of glucose transporter 4 by estrogen receptor $\beta$," Molecular Endocrinology, vol. 25, no. 12, pp. 2017-2028, 2011.

[34] J. Soronen, P.-P. P.-P. Laurila, J. Naukkarinen et al., "Adipose tissue gene expression analysis reveals changes in inflammatory, mitochondrial respiratory and lipid metabolic pathways in obese insulin-resistant subjects," BMC Medical Genomics, vol. 5, article 9, 2012.

[35] N. Viguerie, E. Montastier, J. J. Maoret et al., "Determinants of human adipose tissue gene expression: impact of diet, sex, metabolic status, and cis genetic regulation," PLOS Genetics, vol. 8, Article ID e1002959, 2012.

[36] E. Rampersaud, C. M. Damcott, M. Fu et al., "Identification of novel candidate genes for type 2 diabetes from a genome-wide association scan in the old order amish: evidence for replication from diabetes-related quantitative traits and from independent populations," Diabetes, vol. 56, no. 12, pp. 3053-3062, 2007.

[37] C. Fromm-Dornieden, S. von der Heyde, O. Lytovchenko et al., "Novel polysome messages and changes in translational activity appear after induction of adipogenesis in 3T3-L1 cells," BMC Molecular Biology, p. 13, article 9, 2012.

[38] T. P. Stewart, H. Y. Kim, A. M. Saxton, and J. H. Kim, "Genetic and genomic analysis of hyperlipidemia, obesity and diabetes using (C57BL/6J × TALLYHO/JngJ) F2 mice," BMC Genomics, vol. 11, no. 1, article 713, 2010.

[39] J. Naukkarinen, I. Surakka, K. H. Pietiläinen et al., "Use of genome-wide expression data to mine the "Gray Zone" of GWA studies leads to novel candidate obesity genes," PLoS Genetics, vol. 6, no. 6, Article ID e1000976, 2010.

[40] C. Gubser, D. Bergamaschi, M. Hollinshead, X. Lu, F. J. M. van Kuppeveld, and G. L. Smith, "A new inhibitor of apoptosis from vaccinia virus and eukaryotes," PLoS Pathogens, vol. 3, no. 2, p. e17, 2007. 
[41] D. E. Jensen, M. Proctor, S. T. Marquis et al., "BAP1: a novel ubiquitin hydrolase which binds to the BRCA1 RING finger and enhances BRCA1-mediated cell growth suppression," Oncogene, vol. 16, no. 9, pp. 1097-1112, 1998.

[42] H. Abbaszadegan, K. Von Sivers, and U. Jonsson, "Late displacement of Colles' fractures," International Orthopaedics, vol. 12, no. 3, pp. 197-199, 1988.

[43] S.-I. Yoshimura, A. Gerondopoulos, A. Linford, D. J. Rigden, and F. A. Barr, "Family-wide characterization of the DENN domain Rab GDP-GTP exchange factors," Journal of Cell Biology, vol. 191, no. 2, pp. 367-381, 2010.

[44] L. C. Keller, S. Geimer, E. Romijn, J. Yates, I. Zamora, and W. F. Marshall, "Molecular architecture of the centriole proteome: the conserved WD40 domain protein POC1 is required for centriole duplication and length control," Molecular Biology of the Cell, vol. 20, no. 4, pp. 1150-1166, 2009.

[45] C. G. Pearson, D. P. S. Osborn, T. H. Giddings Jr., P. L. Beales, and M. Winey, "Basal body stability and ciliogenesis requires the conserved component Pocl," Journal of Cell Biology, vol. 187, no. 6, pp. 905-920, 2009. 


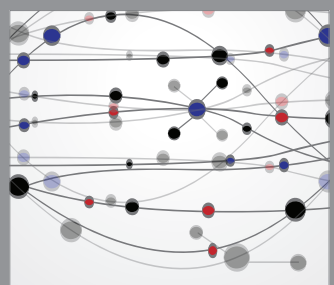

The Scientific World Journal
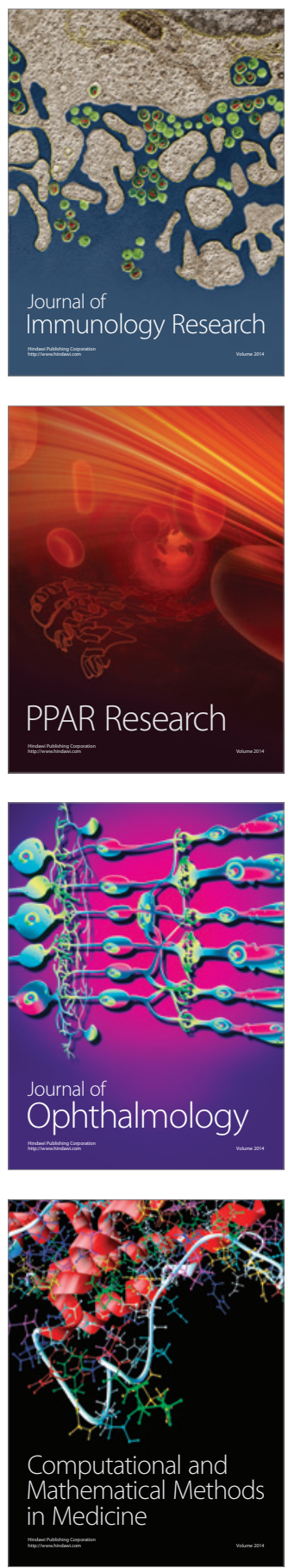

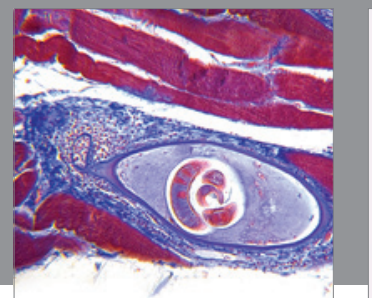

Gastroenterology

Research and Practice
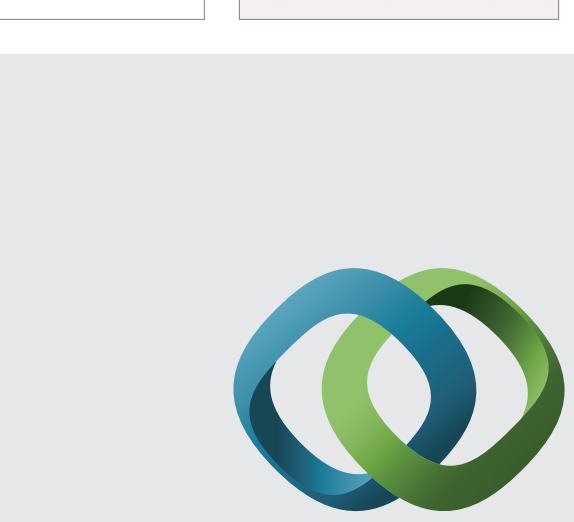

\section{Hindawi}

Submit your manuscripts at

http://www.hindawi.com
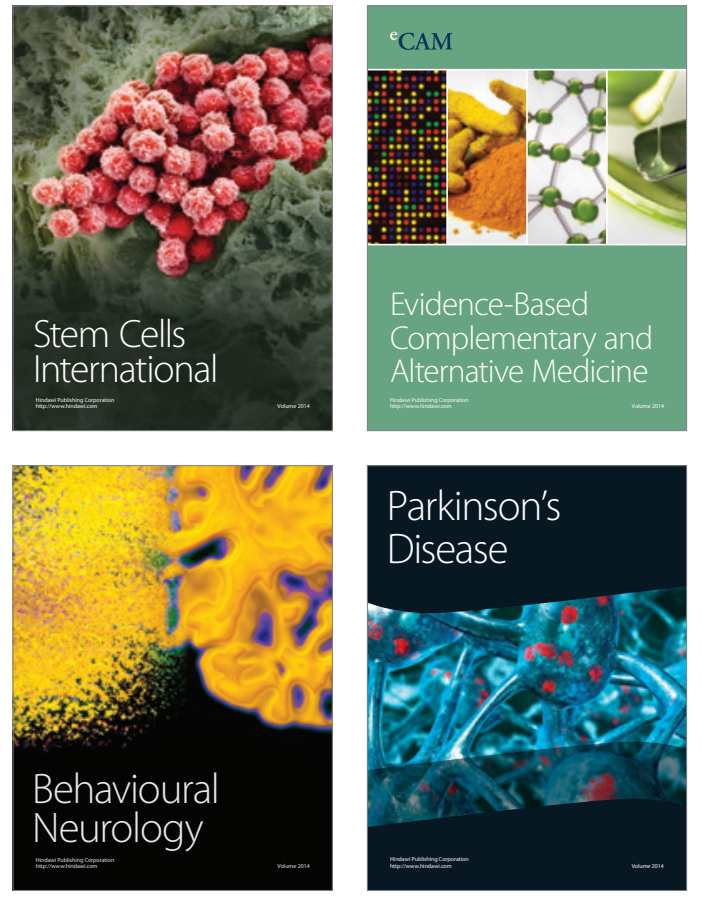
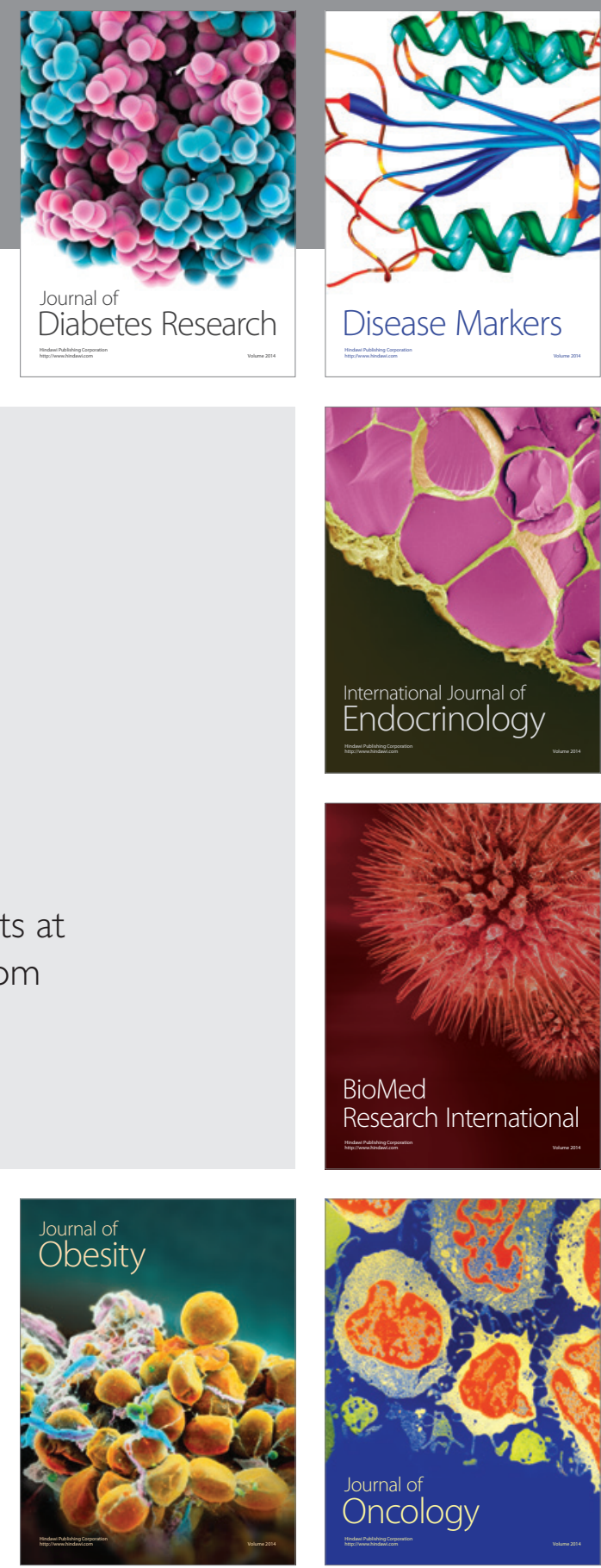

Disease Markers
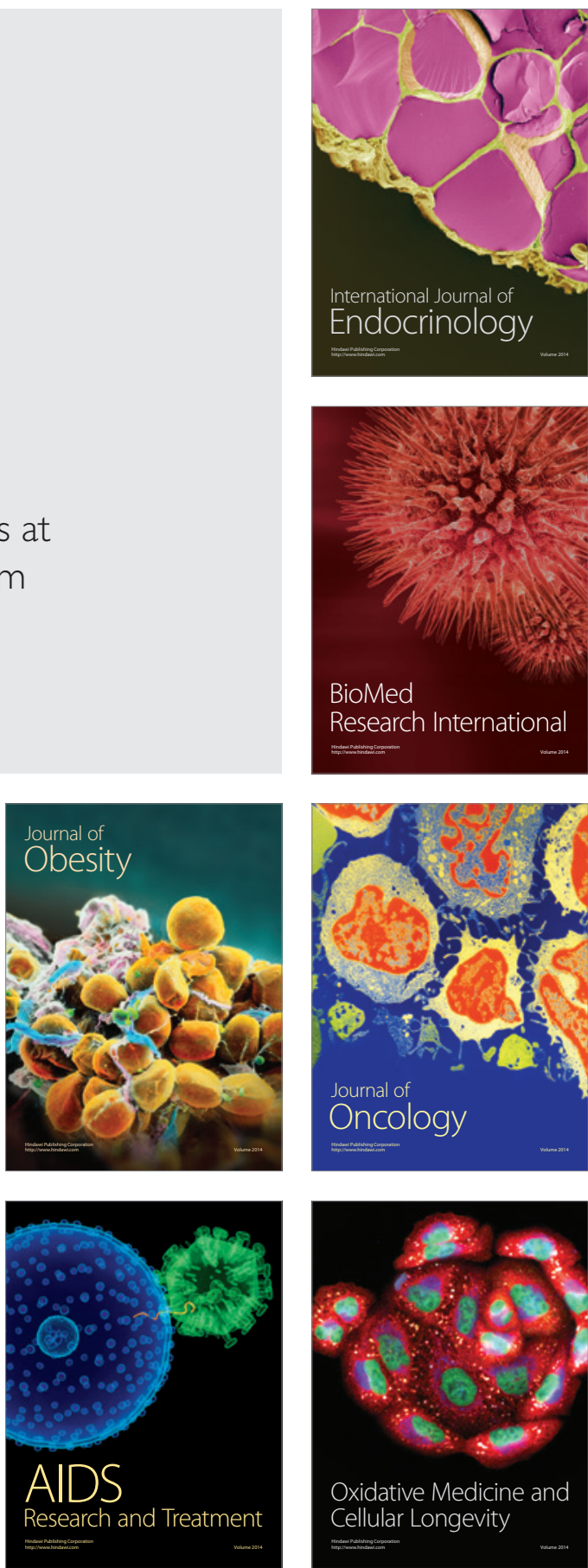